\title{
Amelioration and arable land-use possibilities of Solonetz soils in the Trans-Tisza region of Hungary
}

\section{LAJOS BLASKÓ}

University of Debrecen, Faculty of Agricultural and Food Sciences and Environmental Management, Institute of Water and Environmental Management, Debrecen, Hungary

blasko@agr.unideb.hu

\section{Summary}

Salt affected soils cover about 1 million hectares in Hungary. This paper is based on the research results obtained at the Karcag-puszta long-term experimental site, where, depending on the catena, crusty (A horizon $=0-7 \mathrm{~cm}$ ), medium (A hor. $=8-$ $20 \mathrm{~cm}$ ) and deep (A hor. $>20 \mathrm{~cm}$ ) subtypes of the Meadow Solonetz soil could be found. The chemical reclamation was made specifically for the given site. Lime was applied on the soils with neutral or slightly acidic top layer, while on the soils with alkaline top layer, gypsum was applied. As regards internal drainage, a tube system with an average depth of $1 \mathrm{~m}$ and 5, 10 and $15 \mathrm{~m}$ drain spacing was constructed. Decreasing salt and sodium content could be measured both in drained and non-drained soils. The advantage of drainage was that the leachingout extended to the whole layer above the drain pipes, while without drainage, the $\mathrm{Na}$ ions exchanged from the upper layers still accumulated at a depth of 60$100 \mathrm{~cm}$. In the first two decades, the groundwater level was deeper and leaching was the dominant process. Since 2004, due to the frequently high groundwater level, the leaching and deepening of the fertile top layer has been slower.

Keywords: salt affected soil, amelioration, arable land-use

\section{Introduction}

According the soil survey (Szabolcs, 1971; Várallyay, 1992), the salt affected soils cover in Hungary about 1 million ha. Salt affected soils (SAS) with structural B-horizon (Meadow Solonetz soils) represent the most wide spread group of SAS in Hungary. Most of them are located in the Trans Tisza Region (geographical region of Hungary east of the River Tisza). About 50 percent of these soils have been reclaimed and used as arable land until now.

The practice of reclamation of the SAS-s is more than two centuries old. In spite of this long history the revaluation of the research and the practical results is important because of the changing economic and ecological environment. 
For an established land use decision - among others - the following questions must be answered:

- What is the main tendency of soil forming processes?

- What is the degree of the soil quality changes for shorter and longer after amelioration?

- What are the most effective means of soil amelioration?

- What are the most suitable cultivated crops on the ameliorated SAS-s?

\section{Materials and methods}

As a contribution to an appropriate answer of the above questions I try to summaries the main research results of a long term amelioration experimental field at Karcag-puszta.

The amelioration model site was set up by László Nyiri in 1977. The detailed introduction of the experiment carried out at that model site was published by Nyiri and Fehér (1977). The pedological and plant production results can be found in more relevant publications (Nyiri and Fehér, 1981; Nyiri, 1988; Blaskó, 2010; Blaskó et al., 2010; Tóth et al., 2017, 2018).

The soil type of the experimental site is a Meadow Solonetz with structural B-horizon, with clay and clay loam texture. The characteristic groundwater depth varies between 1.5 and 2 meters.

On the experimental field the subtypes of the Meadow Solonetz are arranged along a micro-catena. The altitude difference between the highest and lowest point of the experimental field is $0.9 \mathrm{~m}$ (Figure 1). The micro-relief forms basins and valleys with different run-off and run on characteristics. In the areas with different exposure specific water regimes are formed due to different water supply. As a consequence of limited infiltration the rainwater runs off the higher parts. The run-on water keeps the deeper parts of the catena position longer wet. In the deeper parts of the area leaching processes are more intensive (Blaskó, 2004; Blaskó et al., 2006; Gálya et al., 2014).

The characteristic salt and exchangeable sodium profiles of high and low catena positions on the experimental field are demonstrated in Figure 2-3. Mainly depending on the catena - moving from the highest position to the deeper one - the crusty (A-horizon $=0-7 \mathrm{~cm}$ ), medium (A-hor. $=8-20$ $\mathrm{cm}$ ) and deep (A-hor. $>20 \mathrm{~cm}$ ) subtypes of the Meadow Solonetz soil can be found. About on $25 \%$ of the territory in addition to the sodic character $\left(\mathrm{ESP}_{\mathrm{Bhor}}>5 \%\right)$ the saline feature (water soluble salt content in the top layer $>0.15 \%$ ) can be found as well. At the deepest catena position the soil is salt affected only in the deeper layers, so it belongs to the type of nonsalt affected meadow soil. 
Figure 1. Contour map of the experimental field

$\mathrm{m}$ above

Baltic sea level

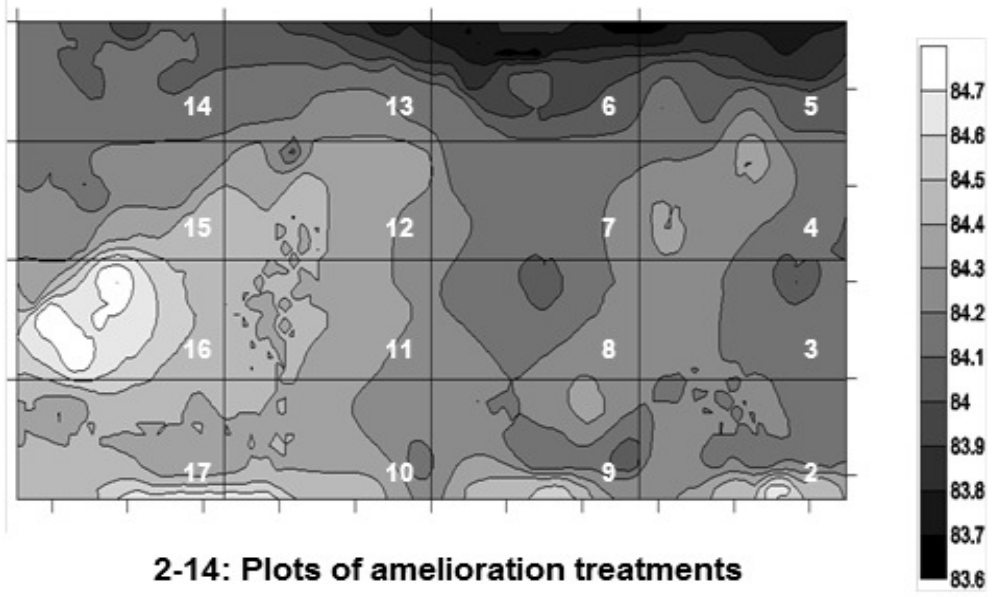

Figure 2. Salt profile of soil at high $(H)$ and low $(L)$ catena position

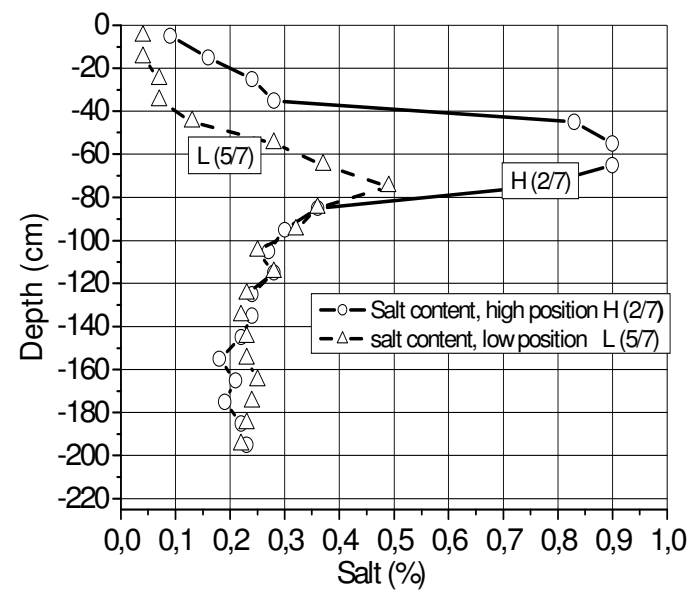

The site specific reclamation treatments on the different subtypes of SAS are represented in Table 1. On the soils with neutral or slightly acidic top layer lime was applied, while on the soils with alkaline top layer gypsum was used. The chemical amendment was spread on the soil surface and mixed in the soil by disc. In the treatments of B-horizon amelioration gypsum was inserted in $40 \mathrm{~cm}$ deep slits opened by a chisel like operator. For regulation of water regime either surface or subsurface 
drainage was constructed. The surface drainage was made by outlet furrows. For internal drainage a tube system with an average depth of 1 $\mathrm{m}$ and 5,10,15 $\mathrm{m}$ drain spacing was constructed. Above the drain tubes a $30 \mathrm{~cm}$ thick gravel filter layer was put.

Figure 3. Exchangeable sodium content of soil at high $(H)$ and low $(L)$ catena position

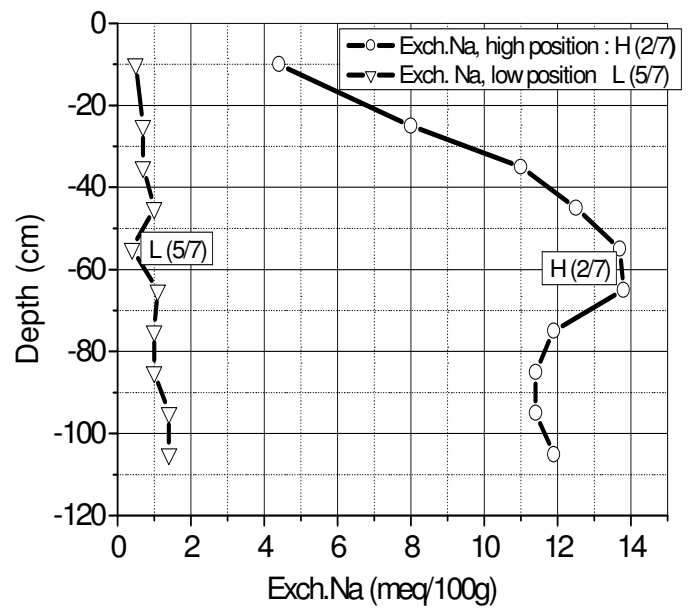

Table 1. Soil sub-types and reclamation treatments of the amelioration experiment

\begin{tabular}{lcc}
\hline \multicolumn{1}{c}{ Treatment } & $\begin{array}{c}\text { Treatment } \\
\text { code }\end{array}$ & Soil subtype \\
\hline Spreading loess on the surface & $(2)$ & \\
Gypsum in A horizon & $(3,17)$ & Crusty Meadow \\
Lime in A horizon & $(11)$ & Solonetz \\
Gypsum in A and B horizon & $(4,16)$ & \\
Lime in A horizon/gypsum in B horizon + 5 m drain & $(7,12)$ & \\
Lime in A horizon/gypsum in B horizon + 15 m drain & $(15)$ & \\
\hline Lime in A horizon/gypsum in B horizon & $(8)$ & Medium Meadow \\
Lime in A horizon/gypsum in B horizon + 10 m drain & $(14)$ & Solonetz \\
\hline Lime in A horizon & $(5)$ & Deep Meadow Solonetz \\
Lime in A horizon +5 m drain & $(6,13)$ & and Meadow soil \\
\hline
\end{tabular}

The amelioration treatments were made without repeat. Treatments The soil samples were taken from 7 points on each plot to $110 \mathrm{~cm}$ depth by $10 \mathrm{~cm}$. Taking samples from these points on each plot was repeated in 1981, 1985, 1989, 1995, 2000 and 2010 The soil samples were analyzed in the laboratory for determination of soil $\mathrm{pH}\left(\mathrm{H}_{2} \mathrm{O}, \mathrm{KCl}\right)$, electrical conductivity, exchangeable cations (Mehlich), AL-soluble $\mathrm{Ca}, \mathrm{Mg}, \mathrm{Na}, \mathrm{K}$, P-contents etc. 
On the experimental plots winter wheat (in 1978, 1979, 1984, 1985, 1987, 1994, 1998, 2007), alfalfa for hay (in 1980, 1981, 1982, 1983, 1989, 1990, 1991, 1992) and for seeds (in 1981, 1982), sunflower (in 1993, 1996, 2002, 2006), millet $(1986,1995,2003)$, winter barley $(2000,2005$, ) rapeseed (2009), sorghum $(2001,2008)$, chickling vetch (1997) was produced. The tillage was made by disc and/or chisel to avoid the turn up of salty layers the ploughing was ignored.

\section{Results and discussion}

Examples of the change of water soluble salt- and exchangeable Nacontent under the influence of amelioration on the parcels covered with Crusty Meadow Solonetz soils are presented in Table 2-3.

Table 2. Change of salt- and exchangeable Na-content under the influence of amelioration on a crusty meadow Solonetz

\begin{tabular}{|c|c|c|c|c|c|c|c|}
\hline \multirow{3}{*}{$\begin{array}{c}\text { Amelioration } \\
\text { treatment }\end{array}$} & \multirow{3}{*}{$\begin{array}{c}\text { Soil } \\
\text { layer } \\
(\mathrm{cm})\end{array}$} & \multicolumn{3}{|c|}{ Salt content } & \multicolumn{3}{|c|}{ ESP } \\
\hline & & \multirow{2}{*}{$\begin{array}{c}\text { Before } \\
\text { amelioration }\end{array}$} & \multicolumn{2}{|c|}{ After amelioration } & \multirow{2}{*}{$\begin{array}{c}\text { Before } \\
\text { amelioration }\end{array}$} & \multicolumn{2}{|c|}{$\begin{array}{c}\text { After } \\
\text { amelioration }\end{array}$} \\
\hline & & & 4. year & 12. year & & 4. year & 12. year \\
\hline \multirow{3}{*}{ (2) MAT } & $0-20$ & 0.23 & 0.09 & 0.03 & 23.0 & 0.9 & 4.2 \\
\hline & $20-30$ & 0.30 & 0.14 & 0.05 & 24.0 & 9.0 & 6.9 \\
\hline & $30-40$ & 0.39 & 0.25 & 0.06 & 29.4 & 19.4 & 14.6 \\
\hline \multirow{3}{*}{ (3) $\mathrm{CaSO}_{4}$} & $0-20$ & 0.19 & 0.20 & 0.04 & 24.0 & 9.5 & 8.6 \\
\hline & $20-30$ & 0.34 & 0.37 & 0.07 & 35.0 & 34.2 & 17.0 \\
\hline & $30-40$ & 0.36 & 0.47 & 0.11 & 36.6 & 43.3 & 25.6 \\
\hline \multirow{3}{*}{ (11) $\mathrm{CaCO}_{3}$} & $0-20$ & 0.12 & 0.13 & 0.07 & 19.6 & 13.7 & 11.5 \\
\hline & $20-30$ & 0.32 & 0.24 & 0.12 & 27.8 & 24.6 & 16.2 \\
\hline & $30-40$ & 0.42 & 0.33 & 0.19 & 32.6 & 29.9 & 22.3 \\
\hline (7) $\mathrm{CaCO}_{3}$ & $0-20$ & 0.19 & 0.14 & 0.08 & 15.0 & 6.2 & 2.0 \\
\hline$\overline{\mathrm{CaSO}_{4}}$ & $20-30$ & 0.29 & 0.26 & 0.09 & 23.4 & 14.1 & 5.0 \\
\hline $\mathrm{D} / 5 \mathrm{~m}$ & $30-40$ & 0.44 & 0.40 & 0.13 & 27.8 & 20.5 & 11.2 \\
\hline
\end{tabular}

Note: $\mathrm{MAT} \mathrm{CaCO}_{3}$ containing subsoil (loess material); $\mathrm{CaCO}_{3} / \mathrm{CaSO}_{4}$ amendment in the top layer/amendment in the deeper layer; D/5 m subsurface drainage/drain distance.

According the data a decreasing salt and sodium content could be measured both in drained and non-drained soils.

The advantage of drainage is that leaching out extends to the whole layer above the drain pipes, but without drainage the $\mathrm{Na}$ ions exchanged from the upper layers still accumulate at the depth of 60-100 cm (Table 3). In the first two decades the leaching of salts was the dominant process. From 2004 the high ground water level was more frequent (Figure 4). As a consequence of increasing ground water level in the deeper layers of the non-drained soils a new salt accumulation process began and the deepening of top layer with low salt and sodium content was much slower, than in the first two decades. 
Table 3. Change of exchangeable sodium content (meq $100 \mathrm{~g}^{-1}$ )

\begin{tabular}{|c|c|c|c|c|}
\hline \multirow{2}{*}{$\begin{array}{l}\text { Depth } \\
(\mathrm{cm})\end{array}$} & 2 & 3 & 4 & 12 \\
\hline & MAT D/0 & $\mathrm{CaSO}_{4}$ & $\frac{\mathrm{CaSO}_{4}}{\mathrm{CaSO}_{4}}$ & $\frac{\mathrm{CaSO}_{4}}{\mathrm{CaSO}_{4}} \mathrm{D} / 5 \mathrm{~m}$ \\
\hline $0-20$ & $-6.71^{* *}$ & $-5.56^{* *}$ & $-5.17^{* *}$ & $-5.81^{* *}$ \\
\hline $20-30$ & $-6.67^{* *}$ & $-8.14^{* *}$ & $-6.79 * *$ & $-9.60^{* *}$ \\
\hline $30-40$ & $-6.60 * *$ & $-4.93^{* *}$ & $-3.93^{* *}$ & $-9.77^{* *}$ \\
\hline $40-50$ & $-4.48^{*}$ & -0.04 & 1.17 & $-8.93^{* *}$ \\
\hline $50-60$ & -2.80 & 1.46 & $2.87^{*}$ & $-6.53^{* *}$ \\
\hline $60-70$ & 0.20 & $3.34^{*}$ & $4.67^{* *}$ & $-5.89 *$ \\
\hline $70-80$ & 2.18 & $3.7^{* *}$ & $5.68^{* *}$ & $-5.20^{*}$ \\
\hline $80-90$ & 2.00 & $3.17^{* *}$ & $6.33^{* *}$ & -0.33 \\
\hline $90-100$ & $2.47^{*}$ & $3.68^{* *}$ & $4.54^{*}$ & $-3.17^{*}$ \\
\hline 100-110 & $2.74^{*}$ & 2.46 & $5.36^{* *}$ & -1.83 \\
\hline
\end{tabular}

Figure 4. Change of groundwater level between 2000 and 2010 at Karcag-puszta experimental field

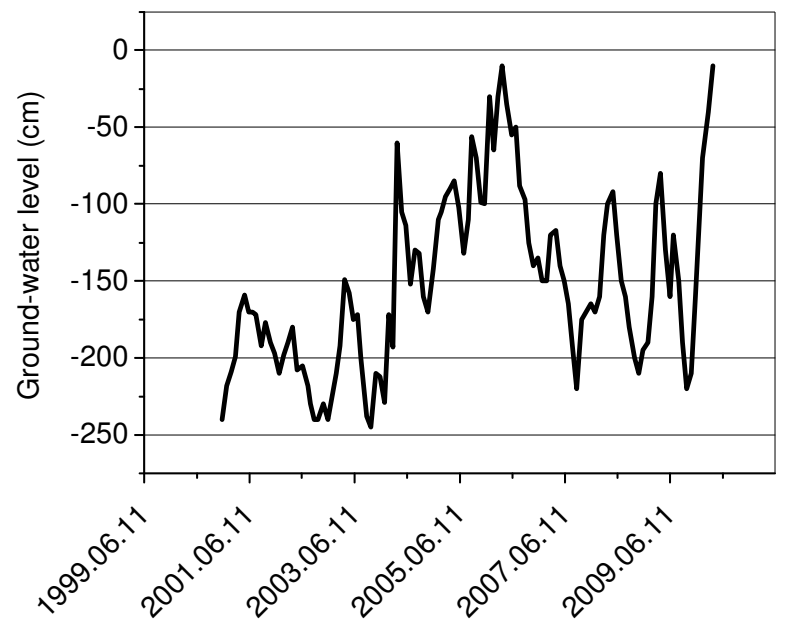

Determination of the critical threshold concentration of $\mathrm{Na}$ based upon the correlation between AL-soluble $\mathrm{Na}$ and capillary rise (Figure 5) and nitrate content (Figure 6) of the soil. The data show that from viewpoint of these characteristics the "critical" Na content for this soil is 4 meq $100 \mathrm{~g}^{-1}$.

The fertility of salt affected soils is in close relationship with the depth of leached out A-horizon. Thus for quantification of soil improvement the depth of top layer with $\mathrm{Na}$ content lower than 4 meq $100 \mathrm{~g}^{-1}$ was considered (Table 4). 
Figure 5. Capillary rise as function of sodium content

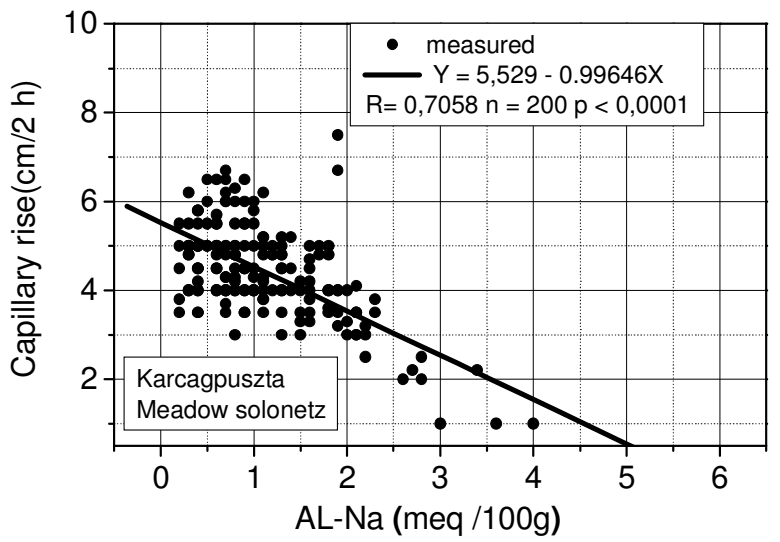

Figure 6. Nitrate content of soil as function of sodium content

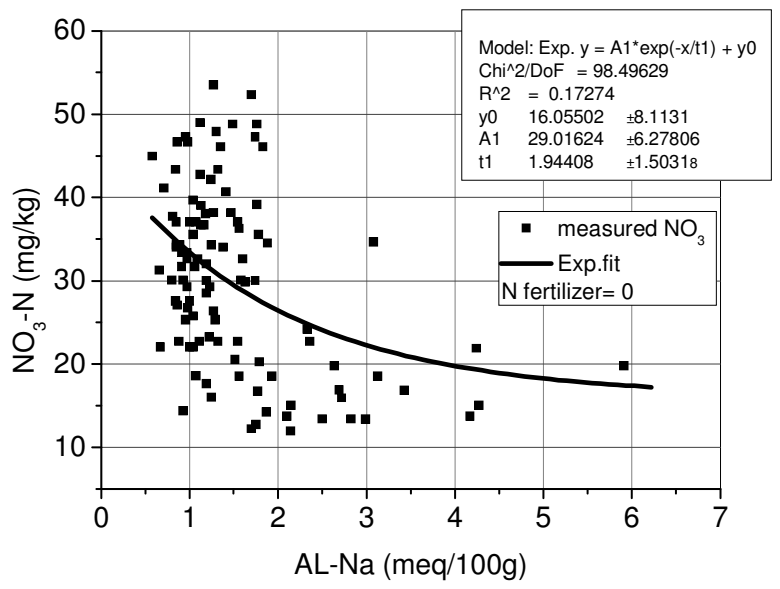

Revealing the salt regime processes is of great importance in judging the reclamation and utilization possibilities of salt affected soils. Although groundwater control ceasing the cause of salinization is the only definitive, relatively fast and irreversible solution for plough land use of salty soils, but salt affected soils are not worth being reclaimed under the recent economic circumstances if only drainage could impede the re-salinization of top layers. In the case of subsurface drainage leaching occurs in the soil layer above the drains, the risk of resalinization is low, but recently and in the near future drainage has no reality due to economic reasons, hence determination of the degree of changes achievable without drainage is more important. By means of the 
application of chemical amendments and deep-loosening the thickness of the fertile topsoil with low salt content can be deepened with approximately $10 \mathrm{~cm}$ in ten years' time. An even more effective procedure among the soil reclamation methods without drainage is the application high amount $\left(500 \mathrm{~m}^{3} \mathrm{ha}^{-1}\right)$ of the $\mathrm{CaCO}_{3}$-containing subsoil material, which enriches the Ca-content and deepens directly the original A-horizon.

Table 4. Depth of top layer with low Na content

\begin{tabular}{|c|c|c|c|c|}
\hline \multirow{2}{*}{ Treatment } & \multicolumn{4}{|c|}{ Years } \\
\hline & 1977 & 1989 & 2000 & 2010 \\
\hline MAT & 0 & 60 & 40 & 40 \\
\hline $\mathrm{CaSO}_{4}, \mathrm{D} / \mathrm{f}$ & 0 & 40 & 30 & 40 \\
\hline $\mathrm{CaSO}_{4} / \mathrm{CaSO}_{4}$ & 0 & 0 & 20 & 30 \\
\hline $\mathrm{CaCO}_{3}$ & 20 & 30 & $110<$ & $110<$ \\
\hline $\mathrm{CaCO}_{3}, \mathrm{D} / 5 \mathrm{~m}$ & 20 & 70 & 90 & 100 \\
\hline $\mathrm{CaCO}_{3} / \mathrm{CaSO}_{4}$ & 0 & 40 & 90 & 100 \\
\hline $\mathrm{CaCO}_{3} / \mathrm{CaSO}_{4}, \mathrm{D} / \mathrm{f}$ & 20 & 40 & 60 & 70 \\
\hline $\mathrm{CaCO}_{3} / \mathrm{CaSO}_{4}$ & 0 & 0 & 70 & 70 \\
\hline $\mathrm{CaCO}_{3} / \mathrm{CaSO}_{4}, \mathrm{D} / 90 \mathrm{~m}$ & 0 & 0 & 40 & 50 \\
\hline $\mathrm{CaCO}_{3}, \mathrm{D} / \mathrm{f}$ & 20 & 40 & 40 & 50 \\
\hline $\mathrm{CaCO}_{3} / \mathrm{CaSO}_{4}, \mathrm{D} / 5 \mathrm{~m}$ & 0 & 0 & 40 & 60 \\
\hline $\mathrm{CaCO}_{3}, \mathrm{D} / 5 \mathrm{~m}$ & 20 & 70 & 80 & 100 \\
\hline $\mathrm{CaCO}_{3} / \mathrm{CaSO}_{4}, \mathrm{D} / 10 \mathrm{~m}$ & 0 & 50 & 80 & 90 \\
\hline $\mathrm{CaCO}_{3} / \mathrm{CaSO} 4, \mathrm{D} / 15 \mathrm{~m}$ & 0 & 0 & 50 & 60 \\
\hline $\mathrm{CaSO}_{4} / \mathrm{CaSO}_{4}, \mathrm{D} / \mathrm{f}$ & 0 & 0 & 20 & 20 \\
\hline $\mathrm{CaSO}_{4}, \mathrm{D} / \mathrm{f}$ & 0 & 0 & 0 & 10 \\
\hline \multicolumn{5}{|c|}{$\begin{array}{l}\text { Note: MAT Spreading loess on the surface } 400 \mathrm{~m}^{3} \mathrm{ha}^{-1} ; \mathrm{CaCO}_{3} \text {, or } \mathrm{CaSO}_{4} \text { in the topsoil } \\
\mathrm{CaSO}_{4} \text { in the B horizon; } \mathrm{CaSO}_{4} / \mathrm{CaSO}_{4} \text { Gypsum in } \mathrm{A} \text { horizon/gypsum in B horizon; } \\
\mathrm{CaCO}_{3} / \mathrm{CaSO}_{4} \mathrm{Lime} \text { in A horizon/gypsum in B horizon; D/5, 10, } 15 \mathrm{~m} \text { subsurface drainage } \\
\text { with spacing of } 5,10,15 \mathrm{~m} \text {; D/f surface drainage. }\end{array}$} \\
\hline
\end{tabular}

With no drains salts leached from the topsoil still remain in the layers close to the surface involving the risk of re-salinization due to the rise of the groundwater table. But the occasional rise of the groundwater table started in the middle of the 1990-ies did not lead to re-salinization of such an extent that would have compensated the results of the strong leaching characterized the previous decades.

The fact that processes resulting in salt leaching are dominant to processes causing salt accumulation under the recent weather conditions leads to the conclusion that the reclamation of salt affected soils without the application of drainage can be beneficial in a longer term.

Nevertheless the fact must be taken into consideration that the process of natural leaching is very slow, and the leaching is several times interrupted by salt accumulation caused by higher groundwater level. 
Consequently the deepening of top layer with low $\mathrm{Na}$ content takes decades, even the infiltration and the penetration are accelerated by chemical and physical reclamation. Therefore only those salt affected soils are worth being used as arable-lands and reclaimed which have got at least $15-20 \mathrm{~cm}$ deep leached topsoil even before the reclamation.

To demonstrate the velocity of soil improvement and the plant production benefits due to reclamation in Table 4 the deepening process of the fertile soil layer in time, while in Figure 7 the average yields of crops grown on soils with leached layer of different thickness are displayed.

Figure 7. Relationship between the depth of leached A-horizon and the yields

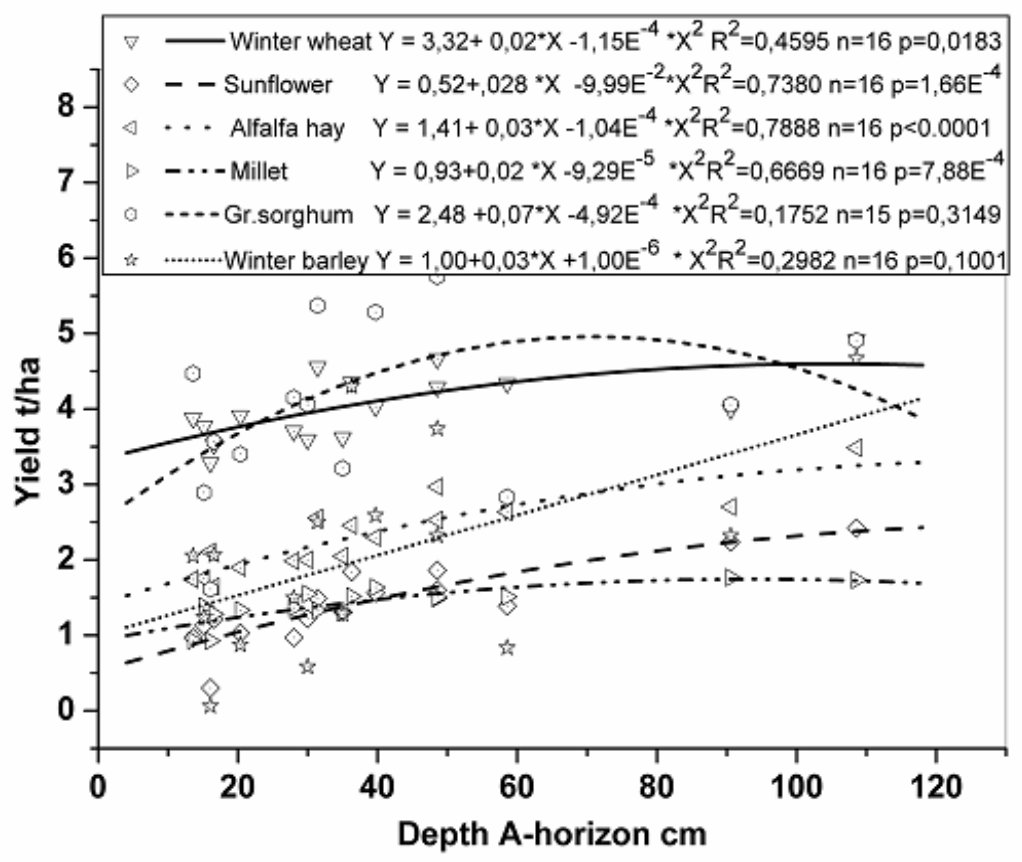

The expectable deepening of the originally $15-20 \mathrm{~cm}$ deep leached top layer due to reclamation ensures the plant-roots to find suitable soil conditions. The reclaimed salt affected soil is suitable for plant production - mainly of cereals with relatively shallow root zone - for quite a long time after amelioration. A deeper fertile A-horizon of the soil has positive influence on the yields of crops with deeper root zone (sunflower, grain sorghum, millet, alfalfa), but their yield increase is lower compared to winter wheat's. 


\section{Conclusions}

On the bases of the results of the investigations carried out at the Karcagpuszta Experimental Site and of the investigations with similar soil conditions the following statements can be made:

- Taking into consideration the yields that can be achieved by various reclamation levels Solonetz soils with A-horizon $20-30 \mathrm{~cm}$ can be used for grain producing fields. For producing crops with deeper root system the top layer with low salt and exchangeable sodium content must be deeper than $40 \mathrm{~cm}$.

- Chemical reclamation of sodic soils with deeper leached upper horizon must be preferred if drainage cannot be applied.

- Among the soil reclamation methods without drainage, distribution of calcium-carbonate containing subsoil can be underlined, because the best crop production and soil-improvement could be achieved by this method.

\section{References}

Blaskó, L. (1996): The possibilities and limits of amelioration of salt affected soils with structural B-horizon. [In: Misopolinos, N. D.-Szabolcs, I. (ed.) Soil Salinization and Alkalization in Europe European Society for Soil Conservation Editions.] Thesaloniki. 109-111,

Blaskó, L. (2004): GIS evaluation of a long-term experiment on salinization processing. In: Conference Proceedings of the $4^{\text {th }}$ International Congress of ESSC. Budapest. 2004. 05. 24-29. 169-173.

Blaskó, L. (2010): Possibilities of sweet sorghum production on the soils of Karcag micro-region. International Seminar on Crop Science for Food Security, Bioenergy and Sustainability. [In: Behl, R. K. et al. (eds.) Crop Science for Food security, Bio-energy and Sustainability: Proceedings of the $3^{\text {rd }}$ IFSDAA International Seminar on Crop Science for Food Security, Bio-energy and Sustainability.] Szeged. 2010. 06. 1-3.

Blaskó, L.-Ábrahám, É. B.-Balogh, I. (2010): Effect of sodium content and NPK fertilizer level on the sweet sorghum production on a salt affected soil. [In: Hera, C. (ed.) $15^{\text {th }}$ World Fertilizer Congress of the International Scientific Centre for Fertilizers (CIEC). Proceedings. Meeting the Fertilizer Demand on a Changing Globe: Biofuels, Climate Change and Contaminants.] Bucarest. 2010. 08. 29.-09.02. Publishing House of the Romanian Academy. Bucarest.

Blaskó, L.-Tamás, J.-Czimbalmos, R. (2006): Substance Regime Processes Depending on Microrelief in aSalt Affected Natural Grassland. Cereal Res. Commun. 34: 143-147.

Filep, Gy.-Blaskó, L. (1997): The Role of Amelioration in Agricultural Land Use. [In: Filep, Gy. (ed.) Land Use and Soil Management.] Debrecen. 68-84. 
Gálya, B.-Bozsik, É.-Szőllősi, N.-Riczu, P.-Blaskó, L.-Tamás, J.-Deák, B.-Bökfi, K.Heilmeier, H. (2014): Modelling of soil properties in a NATURA 2000 habitat site in the Carpathian Basin. [In: Pfeifer, N.-Zlinszky, A. (ed.) Proceedings of the International Workshop on Remote Sensing and GIS for Monitoring of Habitat Quality.] Vienna. 2014. 09. 24-25. Vienna University of Technology. 113-116.

Nyiri L.-Fehér F. (1977): Tájékoztató a Karcag-pusztai komplex meliorációs modelltelepen folyó kutatómunkáról. Kézirat. DATE KI. Karcag.

Nyiri, L.-Fehér, F. (1981): Effects of chemical amelioration and soil moisture regulation on various types of salt affected soils. Agrokémia és Talajtan. 30: (Suppl.) 139-147.

Nyiri L. (1988): A talajjavítás fejlesztésének lehetőségei. Doktori (PhD) tézisek. Karcag. 27.

Szabolcs, I. (ed.) (1971): European solonetz soils and their reclamation. Akadémiai Kiadó. Budapest.

Tóth,T.-Tuba, G.-Zsembeli, J.-Blaskó, L. (2017): Long term effect of the reclamation of solonetz soils. [In: Sarapatka, B.-Bednár, M. (ed.) Degradation and revitalization of soil and landscape: proceedings.] Olomouc. Czech Republic. 2017. 09. 10-13. Palacký University. Olomouc. 160.

Tóth, T.-Tuba, G.-Zsembeli, J.-Blaskó, L. (2018): Relationship between physical and chemical properties of sodic soils in a long-term field reclamation experiment: Abstract. [In: Bieganowski, A. (ed.) 3rd International Symposium of Soil Physics.] Kraków. Poland. 2018. 02. 14-15. Publishing House of the University of Agriculture in Krakow.

Várallyay, Gy. (1992): Soil data base for sustainable land use - Hungarian case study. Proc. Int. Symp. on Soil Resilience and Sustainable Land Use. Budapest. 1992. 09. 28-10. 02. 